\title{
Rethinking communication in innovation processes: creating space for change in complex systems
}

\author{
Cees Leeuwis ${ }^{a}$ and Noelle Aarts ${ }^{b}$ \\ ${ }^{a}$ Communication and Innovation Studies Group, Wageningen University, the Netherlands, cees.leeuwis@wur.nl \\ ${ }^{b}$ Communication Strategies Group, Wageningen University and Communication Science, University of \\ Amsterdam, the Netherlands, noelle.aarts@wur.nl
}

\begin{abstract}
In innovation studies, communication received explicit attention in the context of studies on the adoption and diffusion of innovation that dominated the field in the 1940-1970 period. Since then, our theoretical understanding of both innovation and communication has changed markedly. However, a systematic rethinking of the role of communication in innovation processes is largely lacking. This article reconceptualises the role of everyday communication and communicative intervention in innovation processes, and discusses practical implications. It is argued that we need to broaden our perspective on the types of (communicatively supported) intermediation that an innovation process includes and requires.
\end{abstract}

Keywords: innovation, communication, discursive space, intermediaries, everyday talk

\section{Introduction}

Communication has been a area of interest in innovation studies for a long time. Early studies such as Ryan and Gross (1943) already pay attention to aspects of communication, and this was expanded upon in later works on the adoption and diffusion of innovations (e.g. Rogers, 1962). In those days, communication was looked upon primarily as an intermediary function between science and societal users. The interest in communication even stimulated the emergence of new (applied) academic disciplines such as 'agricultural extension studies', 'health education' and the like. In the last decades, the theoretical understanding of innovation has advanced considerably, and the then dominant 'linear model of innovation' has been replaced by other bodies of thought such as Innovation Systems thinking (Lundvall 1992; Röling 1992; Smits and Kuhlmann, 2004), Strategic Niche Management (Geels, 2002; Schot and Geels, 2008), and Actor Network Theory (Callon et al. 1986). Quite separately, the theoretical understanding of human communication processes has also altered and advanced considerably in the communication sciences. Clearly, these changes in thinking have implications for how we must conceptualise the role of communication in innovation processes. However, a systematic rethinking of the role of communication in innovation processes is largely absent. This article makes an effort to fill this void. We start by summarizing some important changes in thinking in both innovation studies and the communication sciences, and discuss the conceptual implications for understanding the role of communication in innovation processes. We then proceed along two routes. First we discuss the meaning and significance of communication in everyday societal interaction and how this relates to dynamics in complex systems. We then turn to what this implies for deliberate attempts to professionally use communication as a strategy to bring about innovation, whereby we touch upon the functions that communication may support, and the kinds of planning and monitoring that may be of use. In our concluding reflections, we argue that communication can still be regarded as an intermediary process, but that we need to broaden our perspective on the types of intermediation that an innovation process includes and requires. 


\section{Changing views of innovation and communication}

\section{Changes in thinking about innovation}

Over the years, ideas about innovation have evolved considerably. Although there are clearly different strands of thinking, some widely shared shifts are listed in table 1 , and further explained below:

Table 1. Changes in academic thinking about innovation regarding different aspects

\begin{tabular}{|l|l|l|}
\hline Aspect of innovation & $\begin{array}{l}\text { Linear model of innovation } \\
\text { (dominant 1950-1980) }\end{array}$ & $\begin{array}{l}\text { Later modes of thinking } \\
\text { (dominant from 1990 onwards) }\end{array}$ \\
\hline Origin & science and research & $\begin{array}{l}\text { building blocks come from science, practice and } \\
\text { intermediaries }\end{array}$ \\
\hline Nature & new technical device & $\begin{array}{l}\text { new successful combination of technological } \\
\text { devices, modes of thinking and social organisation }\end{array}$ \\
\hline $\begin{array}{l}\text { Social conditions for } \\
\text { application }\end{array}$ & are 'outside' the innovation & are an integral component of the innovation \\
\hline Key processes & R\&D, adoption & interactive design, co-evolution, learning \\
\hline Adoption & is an individual process & $\begin{array}{l}\text { is a collective process within nested networks of } \\
\text { interdependent stakeholders }\end{array}$ \\
\hline Steering & $\begin{array}{l}\text { change can be engineered, predicted } \\
\text { and planned rationally }\end{array}$ & $\begin{array}{l}\text { change is an unpredictable, messy and emergent } \\
\text { process }\end{array}$ \\
\hline Role of science & designing innovations & $\begin{array}{l}\text { delivering inventions that may be turned into } \\
\text { innovations; } \\
\text { responding to questions that emerge in the } \\
\text { innovation process }\end{array}$ \\
\hline Diffusion & happens after the innovation is ready; & $\begin{array}{l}\text { starts already during design, while scaling out often } \\
\text { includes contextual re-design; } \\
\text { focus is on spreading of a process }\end{array}$ \\
\hline
\end{tabular}

The linear idea that innovations are developed by scientists, disseminated through intermediaries and then put into practice by users has been criticised by many (Kline and Rosenberg, 1986; Röling, 1988; Rip, 1995; Leeuwis, 2004). Numerous studies showed that 'innovations' developed by research were often not adopted, and that successful innovations were usually based on an integration of (technological and other) ideas and insights from not only scientists, but also of users, intermediaries and other societal agents. Along with this shift regarding the origins of innovations, the ideas about what an innovation actually is evolved as well. In the past an innovation was regarded as a new technical device or principle - e.g. a photovoltaic cell or a new seed variety. Moreover, the idea was that such an innovation was either adopted or rejected by an individual, depending on all kinds of social conditions (Rogers, 1962). Nowadays, we recognise that innovations -even when considered solely from a technical perspective- are not one-dimensional, but must be viewed as a combination of technical components. In order to work in Dutch society, for example, photovoltaic cells became integrated in solar panels that could be used as roofing materials, and with equipment through which electricity could be measured and fed back into the electricity grid (Van Mierlo, 2002). Clearly, the latter also required new contractual arrangements among dwellers and electricity companies, as well as new role perceptions and adapted policies and legal rules. Thus, innovations do not just consist of new technical devices, but also of new social and organisational arrangements, such as new rules, perceptions, agreements, identities and social relationships. These are no longer considered as external conditions that influence adoption, but rather as integral parts of an innovation. This implies simultaneously, that there are often many different stakeholders (operating in different interdependent networks) involved in an innovation process, and hence that it is not very useful to look at 'adoption' as something that happens only at an individual level. Building on Smits (2000) we can thus conceptualise an innovation as a successful combination of 'hardware' (i.e. new technical devices and practices), 'software' (i.e. new knowledge and modes of thinking) and 'orgware' (i.e. new social institutions and forms of organisation) (adapted from Smits, 2000, 2002).

Not surprisingly, the thinking about innovation as a process has also changed dramatically over the past decades. In former days there was a strong belief in the possibility of planning and predicting

$9^{\text {th }}$ European IFSA Symposium, 4-7 July 2010, Vienna (Austria) 
change and innovation. In contrast, we now see that change is often affected by complex interdependencies, unintended and unforeseen developments and interactions, coincidence and dynamics of conflicts that defy engineering and reductionist understanding (Prigogine and Stengers, 1990; Van Woerkum et al, 2007; Loorbach, 2007). In connection with this, innovation processes are looked at nowadays from an evolutionary perspective. The idea is essentially that a variety of innovations and innovation processes compete in a dynamic selection environment in which the 'best fitting' survives in a given time and space context (Bijker et al., 1987; Rotmans et al., 2001). Clearly, such 'fitting' does not just involve adaptation to prevailing contextual conditions, but also the active influencing, re-design or destruction of pre-existing conditions and frameworks, respectively the 'overthrowing' of previously dominant 'socio-technical regimes' (Geels and Schot, 2007). Thus, innovation processes are conceptualised as conflictive and dependent on dynamics in networks. Consequently, it can be argued that the earlier focus of diffusing a tangible product (a technical device) is unhelpful, since successful innovation depends primarily on the spreading of a collective process from one network context to another. In such a process, stakeholders may or may not succeed to coordinate their actions and achieve an effective and contextually adapted balance between 'hardware', 'software' and 'orgware'.

\section{Changes in thinking about communication}

In the communication sciences, the earlier 'objective model' of communication has been supplemented with a 'subjective model', and more recently by a 'construction model' (see table 2).

When the linear model was dominant in innovation studies, communication was looked at in a rather mechanical and isolated manner, i.e. in terms of the 'objective' model. The process was discussed in terms of individual senders and receivers who exchanged messages (i.e. transferred knowledge and information) through channels and media. If a message did not get across or was not understood, then 'interference' or 'noise' was taken to be the cause. Later, the underlying idea that messages had a fixed meaning was abandoned. It was recognized that the receivers' interpretation of a message was usually quite different from that of the sender. This was caused not so much by 'noise' as by the fact that the sender and the receivers had very different frames of reference and prior knowledge. If a sender wanted to get a certain message across, it was concluded, they had to anticipate the lifeworld of the receiver and had to be prepared to listen as well as send (Dervin, 1981; Röling and Engel, 1990). Although this 'subjective' (or 'receiver-oriented') way of thinking was a big improvement, there were still some shortcomings. It frequently happened that senders were doing their very best to anticipate the receivers' life-world, only to see them almost refuse to understand the message. Despite all kinds of communicative efforts by government and industry to achieve the opposite, for example, European consumers are still not very willing to adapt their views and accept the use biotechnology in food products. In such cases, it is not so much a question of incomprehension or lack of effective communication, but rather of an active and more or less purposeful maintaining of a difference in perception.

In light of these kinds of experiences communication is now regarded as a phenomenon in which those involved construct meanings in interaction (Leeuwis, 1993; Te Molder and Potter, 2005; Aarts and Van Woerkum, 2008). Differences in interpretation have to do not only with different prior knowledge but also with other contextual issues such as the historically grown relationship between the communicating parties, configurations of interests, and also the influence of other actors not directly involved in the interaction. In short, meanings come about -are actively constructed- in a complex context, and are not neutral. And communication is not something that necessarily brings people closer together or aids in problem-solving, but it can also add to incomprehension and the creation and reproduction of problems and conflicts (Aarts, 1998). This latter perspective on communication has less normative connotations than the 'objective' and 'subjective' model, and also does no longer make an absolute distinction between communication and other forms of action. In the earlier models, communication is mainly looked at as a mental and symbolic activity, which may or may not lead people to act in a more physical way (e.g. to adopt a certain technology). In the 'construction model' communication itself is regarded as an action that has direct consequences to 
the (social and material) world, both in the present and future (e.g. relations may be damaged, parties no longer meet, violence may emerge, etc.). At the same time, physical actions are seen to have communicative implications as well; the act of a Minister of Agriculture eating meat in times of BSE is likely to become imbued with meanings by those who observe.

Table 2: Three conceptual models of communication

\begin{tabular}{|c|c|c|c|}
\hline Aspect of communication & Objective model & Subjective model & Construction model \\
\hline $\begin{array}{l}\text { Parties involved in } \\
\text { communication }\end{array}$ & $\begin{array}{l}\text { individual senders and } \\
\text { receivers }\end{array}$ & $\begin{array}{l}\text { senders and receivers which } \\
\text { are part of a community }\end{array}$ & $\begin{array}{l}\text { socially situated actors, in a } \\
\text { relational and historical } \\
\text { setting }\end{array}$ \\
\hline Meaning of message & $\begin{array}{l}\text { is fixed, determined by } \\
\text { sender }\end{array}$ & $\begin{array}{l}\text { sender and receiver have } \\
\text { different interpretations }\end{array}$ & $\begin{array}{l}\text { actors strategically mobilise } \\
\text { meanings to achieve social } \\
\text { ends }\end{array}$ \\
\hline $\begin{array}{l}\text { Main cause of differences } \\
\text { in interpretation }\end{array}$ & $\begin{array}{l}\text { interference / noise in } \\
\text { communication channels }\end{array}$ & $\begin{array}{l}\text { different past experiences } \\
\text { and life-worlds }\end{array}$ & $\begin{array}{l}\text { different values, interests } \\
\text { and struggle for } \\
\text { power/influence }\end{array}$ \\
\hline $\begin{array}{l}\text { Theorists implicit } \\
\text { communication ideal }\end{array}$ & $\begin{array}{l}\text { effective transfer of } \\
\text { particular meanings }\end{array}$ & $\begin{array}{l}\text { dialogue to arrive at shared } \\
\text { meaning }\end{array}$ & $\begin{array}{l}\text { none (unless a partisan } \\
\text { position is taken) }\end{array}$ \\
\hline Relevant time horizon & present & past and present & $\begin{array}{l}\text { past, present and } \\
\text { (anticipated) future }\end{array}$ \\
\hline $\begin{array}{l}\text { Consequences of } \\
\text { communication }\end{array}$ & $\begin{array}{l}\text { more or less effective } \\
\text { transfer of information }\end{array}$ & adapted meanings & $\begin{array}{l}\text { adapted meanings, } \\
\text { relations, and influence } \\
\text { with various impacts }\end{array}$ \\
\hline $\begin{array}{l}\text { Key conditions for } \\
\text { 'effective' communication }\end{array}$ & $\begin{array}{l}\text { precision and quality of the } \\
\text { channel }\end{array}$ & anticipation and empathy & $\begin{array}{l}\text { strategy of combining } \\
\text { communicative and other } \\
\text { resources }\end{array}$ \\
\hline Carriers of communication & $\begin{array}{l}\text { symbolic signals transferred } \\
\text { through channels and media }\end{array}$ & $\begin{array}{l}\text { symbolic signals exchanged } \\
\text { through channels and media }\end{array}$ & $\begin{array}{l}\text { all forms of action that } \\
\text { actors engage in that can be } \\
\text { accessed through channels } \\
\text { and media. }\end{array}$ \\
\hline
\end{tabular}

\section{Preliminary conclusion}

From the above signalled changes in thinking we can derive two main implications for our effort to systematically rethink the role of communication in innovation processes. Firstly, we have seen that innovation happens in society, and involves the contextual re-ordering of relations in multiple social networks. Communication obviously plays an important role in such re-ordering, but if we want to understand its role we can no longer think only in terms of 'diffusing' a ready made innovation. Rather, we need to think about it in terms of a process that takes place in the context of the building, design and/or evolution of effectively re-ordered relations between 'hardware, software and orgware'. A second and related implication is that we cannot usefully limit our perspective on the role of communication in innovation by focussing only on the contributions of professional change agents and intermediaries or the likes. As mentioned, innovation is eventually performed by interacting societal agents, which means that the everyday communicative interactions among them are equally if not more important than the communicative efforts of professionals. In sum, we should not only look at communication as a means to transfer and effectuate knowledge and innovation from the top down, but also look at its potential and characteristics in the process of constructing innovations as an outcome of ongoing societal interaction. In the next section we start by discussing the role of communication in the re-ordering of societal networks, and after that we turn to what the implications are for professionals.

\section{Everyday communication and self-organisation}

As has been signalled in innovation studies, complex interdependencies and regularised interaction (including communication) patterns tend to constrain the space for meaningful innovation, not least since a number of actors in the network are likely to have a vested interest in maintaining the 
existing situation. Such vested interests are reflected in the prevailing formal and informal societal rules and arrangements (labelled institutions, structure or regimes) that actors draw upon and reproduce in their interaction (Giddens, 1984; Geels, 2002; Loorbach, 2007). Despites such structural constraints, and despite the experience that deliberately designed changes are not easily achieved and implemented, we see that the world changes continuously, and quite radically at times. Rather than being controlled and engineered, however, self-organisation - i.e. the emergence of order without external control (Nicolis, 1989) - plays an important role in bringing about patterns of change. The term 'self-organisation' does not mean that change happens automatically and without human intentionality, but rather that it emerges as the unintended outcome of numerous intentional actions which interact and interfere with each other in complex ways (Sharpf, 1978; Aarts and Van Woerkum, 2002; Castells, 2004; Aarts, 2007). This shows that latent opportunities for change always exist (even if unacknowledged), and that societal contexts and structural conditions are not only constraining, but also enabling (Giddens, 1984). It is against this background that it becomes relevant to think about 'space for change' (Long, 1984; Cornwall, 2004). In a general sense, 'space' here refers to the room for manoeuvre that exists and/or emerges in a network of interactions at multiple social interfaces. Such space arises from in the interaction between actors, who define (or negotiate) the space for manoeuvre while communicating with each other. Giddens (1984) speaks of the emergence of meaningful change in terms of a gradual process of 'structuration' that takes place in everyday interaction. In such 'micro' contexts, social structures, institutions and wider phenomena at 'macro' level enter the interaction not only in the sense that they are part of actors' mindsets, but also because actors actively mobilise them in their communication with others in the form of 'summary representations' (Knorr-Cetina, 1988:39). Such representations, then, are part of wider discourses in the Foucauldian sense (Foucault, 1974). Thus, discourses and representations, and especially those which are dominant in a certain setting, can be seen as an important mechanism through which both stability and room for manoeuvre are shaped. From a communication perspective, meaningful innovation is dependent on changes in discourses, representations and storylines that are mobilised by interacting social actors. It is through such communicative devices that the world is ordered and re-ordered (Hajer and Laws, 2006; Giddens, 1984). The emergence of 'space for change', then, can be interpreted as being associated with an altering of what we call 'Discursive Space' at different interfaces in a network. This is visualised in Figure 2:

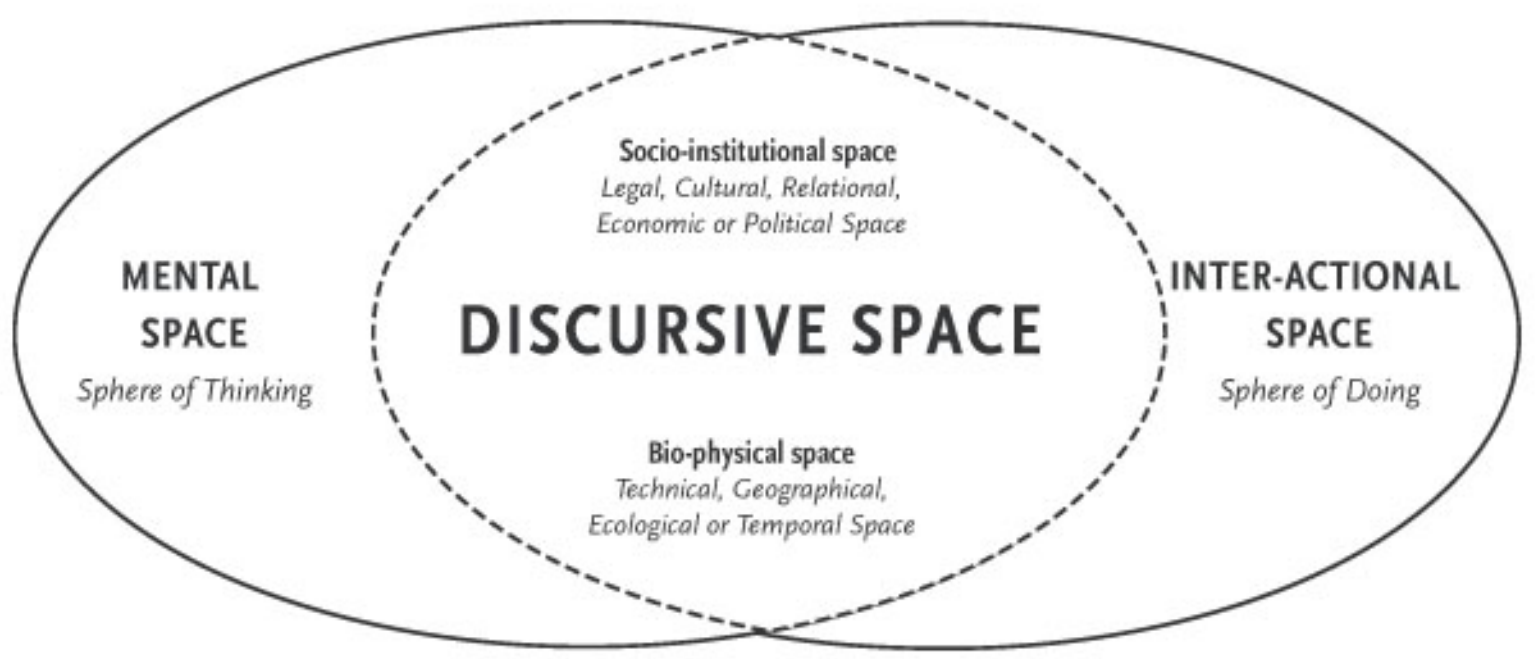

Figure 2: Different types of space and their interrelations.

As is represented in Figure 2, communication (the 'Discursive Space') connects the sphere of thinking ('Mental Space') with the sphere of doing, where people interact with each other and their 
environment ('Inter-Actional Space'). Human beings can be regarded as interpretative beings, whowittingly or unwittingly- draw upon mental schemes (such as. knowledge, aspirations, feelings, evaluations, etc.) when producing (inter)action in the form of language and or physical activity (Giddens, 1984 ; Maturana and Varela, 1984). Thus, the 'sphere of doing' can only be separated from the 'sphere of thinking' analytically. As visualised in Figure 2, connections between these two spheres are forged when human beings exchange meanings with each other through talk and communication in the 'Discursive Space'. Here actors (re)order the world by weaving together (competing) storylines that can be composed of a web of frames, vocabularies and argumentations. When doing so, actors make representations of two other basic forms of space than can be seen to be part of the discursive realm: Socio-Institutional and Bio-Physical Space. That is: they make explicit or implicit statements about, for example, the technical opportunities that exists to solve problems (Technical Space), their cultural acceptability (Cultural Space) and/or the extent to which they need to go along with changes in legal regulations (Legal Space). In many ways, the representation of Socio-Institutional and BioPhysical Space can be interpreted as a critical component in structuration. Naturally, actors representations, storylines and proposals regarding space diverge among different actors, so that different discourses are tend to collide at social interfaces. On the one hand, such collisions can be a driver for change. In that sense, conflict is positive. At the same time, it is clear that meaningful change can only happen when actors eventually develop a certain degree of coherence, complementarity and/or congruence (Röling, 2002; Leeuwis, 2004; Grin and Van der Graaf, 1996) in their mindsets and discourses.. Thus, a potential (multi-faceted) 'space for change' can be seen as a perceived (or expected) and to some extent agreed upon 'room for manoeuvre' or 'window of opportunity' to which further action can be oriented. Such spaces emerge from human interaction and negotiation, and hence their formation is inherently dependent on communication and the development of overlapping discourses.

\section{Communicative intervention}

In this section we investigate the implications of the above outlined perspective on the role of communication in innovation for professionals and interventionists who seek to apply communicative strategies to support innovation.

\section{Conceptualising the overall role of intervention: assisting evolution and shaping latent attractors}

As indicated earlier, the current theoretical understandings of communication and innovation imply that it is no longer useful limit our thinking about the role of change agents and communication professionals to processes of individual adoption and diffusion. We must explore the roles that they can play in the building, design and/or evolution of effectively re-ordered relations between 'hardware, software and orgware'. This while recognizing at the same time that they cannot (and hence should not aspire to) control such processes; change agents may have an influence, amidst the influences of many other actors and factors. In more conceptual terms we would like to propose two (compatible) ways of thinking about the role of intervention. From a more evolutionary innovation perspective (Geels, 2002), we would argue that the role of change agents is to enhance the survival chances of initiatives for change, by supporting -through various strategies- that they become more effectively adapted and/or linked to their dynamic selection environment (which itself can also be influenced) than other competing initiatives. When insufficient initiatives for change exist in a problematic situation, they may even do wise to support multiple competing initiatives in order to create sufficient variety (Van Woerkum and Aarts, 2002). In this perspective, there is much emphasis on the temporal provision of 'protected space', in which the innovation initiative does not yet have to compete with the existing 'regime', but gets the time to become more 'mature' and better adapted through learning experiences (Geels, 2002). This first broad perspective on the role of intervention tends to emphasize the need to 'struggle' with (e.g. influence, lift, adapt, ignore) existing constraints and regimes. These also play an important role in complex dynamical systems theory, but in this second perspective we see - relatively speaking - more attention for opportunities and potentials for change. Even if authors in this field emphasize that systems are dynamic and 
changing continuously, they also signal that they tend towards a relatively stable state which is labelled 'an attractor'. Attractors can be seen as "a state or a reliable pattern of changes (e.g. periodic oscillations toward which a dynamical system evolves over time and to which the system returns after it has changed" (Coleman et al, 2007a: 5). Despite considerable efforts, interventions and dynamics over the past decades, for example, many renewable energy sources continue to be in a 'marginal' state, while the fossil fuel based energy system remains 'dominant' despite several oil crisis and other upheavals (Urry, 2003). This is visualised by Figure 3.
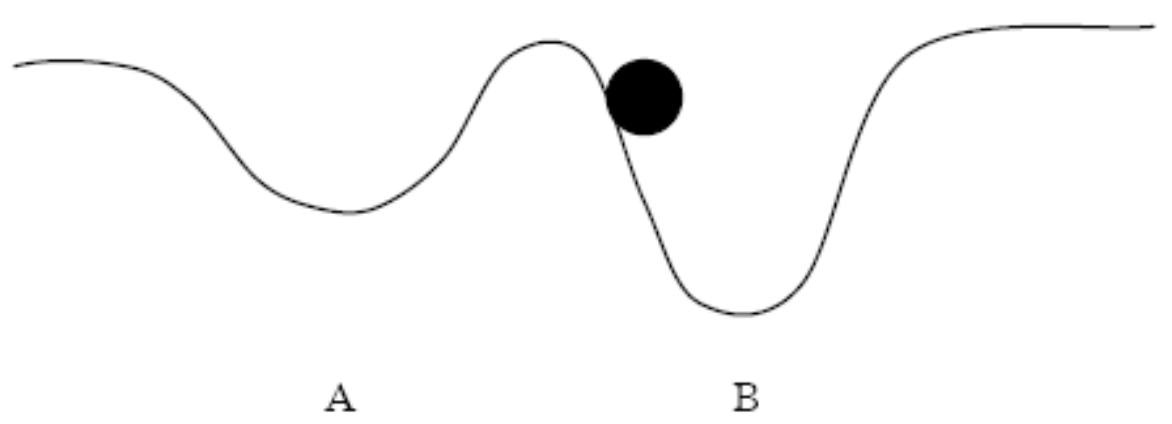

Figure 3: A dynamical system with two attractors (A + B) (Source: Coleman et al., 2007b).

Although the precise the state of a system (represented by the black ball) fluctuates continuously, it tends to gravitate towards attractor B (e.g. 'dominance of fossil fuels'). If sufficiently perturbed to overcome the hurdles in the landscape of attractors (i.e. has enough 'energy' to reach the top of the 'mountain'), the state of the system can in principle shift suddenly towards attractor A (e.g. 'breakthrough of renewable energy'). However, it is very unlikely that a single intervention aimed at a specific target will yield such a result. Due to the web of relationships involved in a complex system, such an intervention may simultaneously have 'positive' and 'negative' influences on achieving certain ends. If, for example, an Minister of Environment decides to heavily subsidise the solar energy sector, this may at the same time result in intensified coalition building among oil companies and a possibly successful challenging of the subsidy programme before the European Court of Justice on grounds of false competition.

It is important to note, however, that not only the momentary state of the system, but also the landscape of attractors may change over time. Figuratively speaking, the 'basin' of an attractor can be seen to become wider or narrower, as well as deeper or shallower, which significantly influences the ease with which a system may shift into another attractor. Thus, even when a situation can still be characterised as 'war', the hurdles to 'peace' may be reduced over time. The important implication here is that an important role of change agents is to 'change the potential for change', rather than to achieve a desired system state. The latter becomes only feasible when an attractor landscape has changed sufficiently to allow for a different attractor to be reached. Below, we outline more specific implications regarding the roles of communication.

\section{Functions of communication}

From a sociological perspective, attractor landscapes, social structures, institutions and regimes have much in common. From a communication perspective, we have seen that changing them coincides and takes place through the adaptation of storylines and discourses through which actors order the world. Such adaptations must somehow be sufficiently complementary, congruent or agreed upon (Grin and Van de Graaf, 1996) across different actors and networks, and must at some point in time resonate within society.

Building on different strands of literature, we argue that three (simultaneous) processes deserve particular attention and support by communication professionals in order to contribute to this. The 
first process is that of network building. We have seen that innovation inherently implies a reconfiguration of relationships within and between networks, and possibly the formation of new networks and/or the demise of existing ones (Engel, 1995; Callon et al, 1986; Latour, 1987). A second key process is supporting social learning. In different strands of thinking about innovation, learning is considered a critical process for developing a conducive fit between innovations and their environment (Geels, 2002; Rotmans, 2003; Smits and Kuhlmann, 2004; Hommels et al, 2007). Moreover, the development of congruent storylines and discourses (Hajer and Laws, 2006; Grin and Van de Graaf, 1996) requires that the parties involved slowly develop overlapping -or at least complementary - perspectives on relevant models of reality, problems, goals and boundaries as a basis for identifying desirable, feasible and acceptable options for change. Dialectical debate and joint learning are proposed as the main route towards achieving this (Checkland, 1988); several scholars have labelled this process 'social learning' (Dunn, 1971, Friedmann, 1984, Röling, 2002, Woodhill, 2002; Leeuwis, 2002). The third key process that can be supported by communication professionals is the dealing with dynamics of power and conflict. We have seen that efforts to change the status quo are likely to lead to tensions and conflicts of various kinds. Moreover, the realisation of change in one way or another involves the mobilisation of power resources to overcome resistance. Our point here is not that dynamics and power and conflict must be prevented; instead we argue that they are always at play, but that there are more and less productive ways of dealing with them.

Theoretical and practical literature on learning, negotiation, participation and communication provide numerous insights and suggestions on how the three basic processes indicated earlier could (depending on a specific context) be facilitated and enhanced through communicative strategies (see table 3).

Table 3. Examples of possibly relevant communicative strategies for enhancing the basic processes relevant to innovation support. [sources: Pretty et al, 1995, Loorbach, 2007; Smits and Kuhlmann, 2004; Weisbord and Janoff ,1995; Aarts, 1998; Pruitt and Carnevale, 1993; Leeuwis, 2004].

\begin{tabular}{|c|c|c|}
\hline network building & supporting social learning & $\begin{array}{l}\text { dealing with dynamics of power and } \\
\text { conflict }\end{array}$ \\
\hline $\begin{array}{l}\text { - make an inventory of existing } \\
\text { initiatives, complemented with } \\
\text { stakeholder analysis; } \\
\text { - build on existing initiatives for } \\
\text { change and the networks } \\
\text { around these; } \\
\text { - arrange contact between } \\
\text { disconnected networks who } \\
\text { may have compatible interests } \\
\text { (e.g. Chinese consumers and } \\
\text { African farmers); } \\
\text { - work towards 'coalitions of } \\
\text { the willing' and exclude actors } \\
\text { who do not feel } \\
\text { interdependent; } \\
\text { - mobilise pressures from } \\
\text { outside (carrots and sticks) to } \\
\text { enhance feelings of } \\
\text { interdependence; } \\
\text { - forge/broker contact } \\
\text { between existing networks and } \\
\text { outsiders and/or outside } \\
\text { expertise; }\end{array}$ & $\begin{array}{l}\text { - demonstrate and visualise interde- } \\
\text { pendencies among stakeholder practices; } \\
\text { - explore and exchange stakeholder } \\
\text { perspectives (values, problems, aspirations, } \\
\text { context, etc) through discussion, role playing, } \\
\text { dramatization, visits, filmed interviews, } \\
\text { informality, humour, fun etc. } \\
\text { - visualise invisible bio-physical processes } \\
\text { with the help of discovery learning tools or } \\
\text { simulation; } \\
\text { - explore past and current trends and likely } \\
\text { futures if nothing changes; } \\
\text { - use visioning tools and scenario analysis to } \\
\text { imagine (and find common ground on) } \\
\text { possible futures } \\
\text { - discuss institutional and other influences } \\
\text { that reinforce existing patterns/problems; } \\
\text { - organise contact with others who have } \\
\text { encountered and managed similar problems; } \\
\text { - elicit uncertainties that hinder change, and } \\
\text { design collaborative investigation and } \\
\text { experimentation to develop common } \\
\text { starting points; } \\
\text { - use practical actions and experiments as } \\
\text { source of reflection and learning, rather than } \\
\text { organising discussion and reflection only; } \\
\text { - organise regular reflection on process }\end{array}$ & $\begin{array}{l}\text { - identify and propose process } \\
\text { facilitators who are credible and } \\
\text { trusted by the stakeholders involved; } \\
\text { - work towards process agreements, } \\
\text { including dealing with media, } \\
\text { mandates, etc.; } \\
\text { - probe to explicate the interests and } \\
\text { fears that underlie mobilised } \\
\text { arguments and counter-arguments; } \\
\text { - steer collaborative research activities } \\
\text { (see other column) to questions } \\
\text { relevant to less resourceful } \\
\text { stakeholders; } \\
\text { - make stakeholders talk in terms of } \\
\text { proposals and counter-proposals; } \\
\text { - ensure regular communication with } \\
\text { constituents to take them along in the } \\
\text { process; } \\
\text { - translate agreed upon problems and } \\
\text { solutions into storylines and symbols } \\
\text { that are likely to resonate in society; } \\
\text { - use media and lobby tactics to } \\
\text { influence societal agenda's and } \\
\text { advocate solutions (with the help of } \\
\text { storylines/symbols) }\end{array}$ \\
\hline
\end{tabular}


As can be noted from the above, current ways of thinking about innovation and communication imply that communication professionals can usefully engage in a much wider array of activities than the (persuasive or advisory) provision of information in individual decision-making about (non-)adoption, and/or organising horizontal exchange to support the diffusion of early-adopter experiences to a wider audience. Instead, the activities outlined in Tables 3 typically encompass multiple tasks and roles in the sphere of process preparation, intermediation and facilitation.

\section{Conclusion}

The starting point for this paper was that, despite major theoretical developments in both the innovation and communication sciences, there has been little specific and explicit attention to integrating these largely separate developments into a reconceptualised view on the role of communication in innovation processes. As a result, explicit attention to communication and communication professionals is still often associated with linear terms such as diffusion and dissemination. And although it is self-evident that communication is an essential process in more interactive, constructive, evolutionary or system-oriented approaches, it is dealt with in a rather implicit way. In this paper we have made an effort to be more explicit, and to systematically rethink the role of communication in innovation processes. In the process of doing so, our resumé of major theoretical shifts in the innovation and communication sciences led to two insights with important implications for re-articulating the role of communication. We established that innovation is a collective process that involves the contextual re-ordering of relations in multiple social networks, and that such re-ordering cannot be usefully understood in terms of 'diffusing' ready-made innovations. Hence we concluded that we need to think about communication as playing a role in innovation development and design. Secondly, we concluded that focussing on the role of communication professionals and deliberate communication would be a far too limited approach, and that the everyday communicative exchanges among societal agents are likely to be of critical significance in connection with the re-ordering of social relationships. Recent understandings suggest that everyday communication is not just about exchanging meanings, but that it is a form of social action that is important in processes of structuration (i.e. the production and reproduction of social structures, including socio-technical regimes and institutions) and the emergence of new order through self-organisation. These are critical processes in current thinking about innovation, which underlines the importance clarifying the role of both everyday and professional communication. We argued that (different forms of) space for manoeuvre and (structural) change are negotiated in the everyday discursive space, where interacting agents develop and propose storylines, discourses and representations (related to a.o. socio-institutional and bio-physical space) that may become dominant and guide further (inter)action and innovation. Due to the complex nature of innovation and innovation processes, change agents and communication professionals are unlikely to be effective if they conceptualise their role as the communicative engineering and planning of predefined changes. At a more abstract level, we have argued that we may look at their role as facilitating that 'the potential for change' increases in a complex dynamical setting, which may include efforts to enhance the survival chances of existing initiatives for change, by facilitating that they become more effectively adapted and/or linked to their dynamic selection environment than competing initiatives. In practical terms, this involves applying a range of process facilitation strategies in the sphere of network building, social learning and conflict management. While in the linear model communication was primarily seen as an intermediary function between science and practice, we now see a much broader range of intermediary roles. As indicated in Table 3, these include e.g. mediation in conflict situations; network and knowledge brokerage; facilitation of exchange, learning and vision building among diverse communities; matching of supply and demand of innovation support services (e.g. research); etc. Moreover, the intermediary roles that we are discussing now happen at a range of interfaces that are situated within (and between) nested networks of stakeholders operating in different societal spheres. In terms of substance, such intermediary processes do not mainly address the qualities of given technologies in connection with 
assumed or proposed problems (as in the linear model), but rather centre on a range of human aspects and attributes that bear relevance to the building of networks and reaching agreement, coherence and congruence (Röling, 2002; Grin and Van de Graaf, 1996) within and between them. Such attributes include e.g. stakeholder characteristics, interests, perspectives, motives, agenda's, fears, visions, uncertainties, questions, demands, represented possibilities and impossibilities, etc., as woven together into discourses and storylines. This broadened perspective on intermediation (in terms of functionality, interfaces, and substance) is largely in line with roles outlined in recent literature on intermediaries (Howells, 2006; Klerkx and Leeuwis, 2008a, 2008b), intermediary organisations (Van der Meulen et al, 2005; Boon et al., 2008), brokerage (Klerkx and Leeuwis, 2008b), boundary arrangements (Hoppe, 2005) and studies on the role of 'systemic instruments' in innovation systems (see Smits and Kuhlmann, 2004; Van Lente et al., 2003; Hekkert et al., 2007). Both in innovation theory and practice classical intermediaries focussing on disseminating technology are being complemented by new roles that go along with radically different forms of professional communication. At the same time a range of authors signal that there is still considerable scope for strengthening the quality and position of such new intermediaries in innovation landscapes (Hall, 2005; Smits and Kuhlmann, 2004). In existing organisations especially (e.g. research and communication establishments) the playing of such new roles tends to require new kinds of communication professionals, organisational mandates and routines, as well as altered incentive structures and funding mechanisms. These do not emerge overnight, and require considerable 'innovation of the innovation system'. However, it is important to signal that much of the recent attention for intermediary processes has been linked to institutionalised and funded intermediaries, that is, those existing in the form of projects, organisations, programmes or firms. Our exploration suggests that everyday communication among stakeholders is of critical importance for the reordering of social relationships and the emergence of space for change in networks. Effective alignment between different stakeholders, networks, spheres, domains and levels is eventually forged in networks of everyday (inter)action, and in that context many forms of 'intermediation' are likely to take place without direct involvement of institutionalised intermediaries. To further clarify the role of communication in innovation processes, more study is needed on the interrelations and role divisions between everyday and intervention-based intermediary processes in innovation trajectories with varying degrees of complexity and ambition.

\section{References}

Aarts, M.N.C. (1998) Een kwestie van natuur; een studie naar de aard en het verloop van communicatie over natuur en natuurbeleid. Published doctoral dissertation. Wageningen Agricultural University, Wageningen.

Aarts, N. (2007), Self-organization in public space: of open networks and closed communities. Paper presented at MOPAN conference 'Learning for Interdependence', Leuven, 28-29 June 2007

Aarts, M.N.C. and C.M.J. Van Woerkum (2002) Dealing with uncertainty in solving complex problems. In: Leeuwis, C. and R. Pyburn (Eds) (2002), Wheelbarrows full of frogs. Social learning in rural resource management. : Assen: Royal Van Gorcum, pp. 421-435.

Aarts, M.N.C. and C.M.J. Van Woerkum (2008) Strategische communicati; Principes en Toepassingen. Assen: Royal Van Gorcum.

Bijker, W., T. Hughes and T. Pinch (Eds) (1987) The social construction of technological systems. New directions in the sociology and history of technology. MIT-Press, Cambridge MA.

Boon, W.PC., E.H.M. Moors, S. Kuhlmann and R.E.H.M. Smits (2008), Demans articulation in intermediary organizations: The case of orphan drugs in the Netherlands.technological Forecasting and Social Change, 75(5): 644-671.

Callon, M., J. Law and A. Rip (Eds) (1986) Mapping the dynamic of science and technology: Sociology of science in the Real World. London: Macmillan. 
Castells, M. (2004) The Power of Identity. The information Age: Economy, Society and Culture Vol. II. Cambridge: Blackwell.

Checkland, P.B. (1988) Soft systems methodology: An overview. Journal of Applied Systems Analysis, 15: 27-30.

Coleman, P.T., R. T. Vallacherer, A. Nowak L. Bui-Wrzosinska (2007a) Intractable conflict as an attractor. A dynamical systems approach to conflict escalation and intractability. American Behavioural Scientist (in press)

Coleman, P.T., L. Bui-Wrzosinska, R. T. Vallachere and A. Nowak (2007b) Protracted conflicts as dynamical systems. Unpublished book chapter (in press).

Cornwall, A. (2004) Spaces for transformation? Reflections on issues of power and difference in participation in development. In: Hickey, S and G. Mohan (eds) (2004), Participation from Tyranny to transformation? Exploring new approaches to participation in development. London / New York: Zed Books, pp. 75-91.

Dervin, B. (1981) Mass communication: Changing conceptions of the audience. In: R.E. Rice and W.J. Paisley (Eds) (1981) Public communication campaigns. Beverly Hills: Sage Publications.

Dunn, E.S. (1971) Economic and social development: A process of social learning. John Hopkins University Press, Baltimore, pp. 71-88.

Engel, P.G.H. (1995) Facilitating innovation. An action-oriented and participatory methodology to improve innovative social practice in agriculture. Published doctoral dissertation. Wageningen Agricultural University, Wageningen.

Foucault, M (1974) The order of things: An archaeology of the human sciences. London: Tavistock Publications.

Friedmann, J. (1984) Planning as social learning. In: D.C. Korton and R. Klaus (Eds) (1984) People centered development: Contributions towards theory and planning frameworks. Kumarian Press, West Hartford, pp.189-194.

Geels, F. (2002) Understanding the dynamics of technological transitions. A co-evolutionary and socio-technical analysis. Twente University Press, Enschede.

Geels, F.W. and J.W. Schot, J.W. (2007) Typology of sociotechnical transition pathways. Research Policy, 36(3): 399-417.

Giddens, A. (1984) The constitution of society: Outline of the theory of structuration. Polity Press, Cambridge.

Grin, J. and H. Van de Graaf (1996) Technology Assessment as learning. Science, Technology and Human Values, 20(1): 72-99.

Hajer, M.A. and D. Laws (2006) Ordering through Discourse. In: M. Moran, M.Rein and R.E. Goodin (eds.) The Oxford Handbook of Public Policy. Oxforf: Oxford University Press, pp. 249-266.

Hall, A. (2005) Capacity development for agricultural biotechnology in developing countries: An innovation systems view of what it is and how to develop it. Journal of International Development 17 (5): 611-630.

Hekkert, M.P., Suurs, R.A.A., Negro, S.O., Kuhlmann, S. AND Smits, R.E.H.M. (2007) Functions of innovation systems: a new approach for analysing technological change. Technological Forecasting and Social Change, 74 (4): 413-432.

Hoppe, R. (2005) Rethinking the science-policy nexus: From knowledge utilization and science technology studies to types of boundary arrangements. Poiesis and Praxis, 3: 199-215.

Hommels, A., Peters, P. and Bijker, W.E. (2007) Techno Therapy or Nurtured Niches? Technology studies and the evaluation of radical innovations. Research Policy, 36 (7): 1088-1099.

Howells, J., (2006) Intermediation and the role of intermediaries in innovation. Research Policy 35: 715-728.

Klerkx , L. and C. Leeuwis (2008a) Matching demand and supply in the agricultural knowledge infrastructure. Experiences with innovation intermediaries. Food Policy, 33: 260-276.

Klerkx, L., and C. Leeuwis (2008b, forthcoming). The emergence and embedding of innovation brokers at different innovation system levels: Insights from the Dutch agricultural sector. Accepted for publication in Technological Forecasting and Social Change. 
Kline, S.J. and N. Rosenberg (1986) An overview of innovation. In: R. Landau and N. Rosenberg (Eds) (1986) The positive sum strategy: Harnessing technology for economic growth. National Academic Press, Washington, pp. 275-305.

Knorr-Cetina, K.D. (1988) The micro-social order. Towards a reconception. In: N.G, Fielding (ed.), Actions and structure. Research methods and social theory. London: Sage, pp 21-53.

Latour, B. (1987) Science in Action. Milton Keynes: Open University Press.

Leeuwis, C. (1993) Of computers, myths and modelling: The social construction of diversity, knowledge, information and communication technologies in Dutch horticulture and agricultural extension. Wageningen Studies in Sociology, Nr. 36. Wageningen: Wageningen Agricultural University.

Leeuwis, C. (2002) Making explicit the social dimensions of cognition. In: Leeuwis, C. and R. Pyburn (Eds) (2002), pp. 391-406.

Leeuwis, C. (with contributions by A. Van den Ban) (2004), Communication for rural innovation. Rethinking agricultural extension. Oxford: Blackwell Science.

Leeuwis, C. and R. Pyburn (Eds) (2002) Wheelbarrows full of frogs. Social learning in rural resource management. Assen: Royal Van Gorcum.

Long, N. (1984), Creating space for change: a perspective on the sociology of development. Sociologia Ruralis, 24 (3-4): 168-184.

Loorbach, D. (2007), Transition Management: new mode of governance for sustainable development. PhDdissertation, Rotterdam: Erasmus University.

Lundvall, B. A. (1992) National systems of innovation: towards a theory of innovation and interactive learning. London: Pinter.

Maturana, H.R. and F.J. Varela (1984) The tree of knowledge: The biological roots of human understanding. Boston: Shambala.

Nicolis, G. (1989) Self-organised criticality: emergent complex behaviour in physical and biological systems. Cambridge: Cambridge University Press.

Pretty, J.N, I. Guijt, J. Thompson and I. Scoones (1995) Participatory learning and action. A trainer's guide. London: IIED.

Prigogine, I and I. Stengers (1984) Order out of chaos: Man's new dialogue with nature. New York: Bantam Books.

Pruitt, D.G. and P.J. Carnevale (1993) Negotiation in social conflict. Buckingham: Open University Press.

Rip, A. (1995) Introduction of new technology: Making use of recent insights from sociology and economics of technology. Technology Analysis and Strategic Management, 7: 417-431.

Rogers, E.M. (1962) Diffusion of innovations, 1st edition. New York: Free Press.

Röling, N.G. (1988) Extension science: Information systems in agricultural development. Cambridge: Cambridge University Press.

Röling, N.G. (1992) The emergence of knowledge systems thinking: A changing perception of relationships among innovation, knowledge process and configuration. Knowledge and Policy: The international Journal of Knowledge Transfer and Utilization, 5: 42-64.

Röling, N.G. (2002) Beyond the aggregation of individual preferences. Moving from multiple to distributed cognition in resource dilemmas. In: Leeuwis, C. and R. Pyburn (Eds) (2002), pp. 25-47.

Röling, N.G. and P.G.H. Engel (1990) IT from a knowledge systems perspective: Concepts and issues. Knowledge in Society: The international journal of knowledge transfer, 3: 6-18.

Rotmans, J. (2003), Transitiemanagement. Sleutel voor een duurzame samenleving. Assen: Van Gorcum.

Rotmans, J., Kemp, R. and Van Asselt, M.B.A. (2001), More Evolution than Revolution: transition management in public policy. In: Foresight, 3 (1): 15-31.

Ryan, B. and N.C. Gross (1943) The diffusion of hybrid seed corn in two lowa communities. Rural Sociology, 8: 15-24. 
Scharpf, F.W. (1978) Interorganizational policy studies: issues, concepts and perspectives. In: Hanf and F.W. Scharpf (eds) (1978). Interorganizational Policy Making: Limits to Coordination and Central Control. London: Sage, pp. 345-370

Schot, J and F. W. Geels (2008) Strategic Niche Management and sustainable innovation journeys. Theory, findings, research agenda and policy. Technology Analysis and Strategic Management, (in press)

Smits, R. (2000) Innovatie in de universiteit. Inaugurele rede. Universiteit Utrecht, Utrecht.

Smits, R. (2002) Innovation studies in the 21st century. Questions from a users perspective. Technological Forecasting and Social Change, 69: 861-883.

Smits, R. and S. Kuhlmann (2004) The rise of systemic instruments in innovation policy. The International Journal of Foresight and Innovation Policy, 1: 4-32.

Te Molder, H. and J. Potter (2005) Conversation and Cognition. Cambridge: Cambridge University Press.

Urry, J. (2003) Global Complexity. Cambridge: Polity Press.

Van der Meulen, B., Nedeva, M., and D. Braun (2005) Intermediaries Organisation and Processes: theory and research issues. Position paper for the PRIME workshop, 6-7 October 2005, Enschede, The Netherlands.

Van Lente, H., Hekkert, M.P., Smits, R.E.H.M. and B. van Waveren (2003) Roles of Systemic Intermediairies in Transition Processes: The Case of Energy Innovation Systems. International Journal of Innovation Management, 7(3): 247-279.

Van Mierlo, B. (2002) Kiem van maatschappelijke verandering. Verspreiding van zonnecelsystemen in de woningbouw met behulp van pilot projecten. Amsterdam, Aksant.

Van Woerkum, C.M.J. and M.N.C Aarts (2002) Wat maakt het verschil. Over de waarde van pluriformiteit in interactieve beleidsprocessen. Innovatie Netwerk Groene Ruimte en Agrocluster, Den Haag.

Van Woerkum, C.M.J., M.N.C. Aarts and K. de Grip (2007). Creativity, planning and organizational change. Journal of Organizational Change Management, 20(6): 847-865.

Weisbord, M.R. and S. Janoff (1995) Future search. An action guide to finding common ground in organizations and communities. San Francisco: Berrett-Koehler Publishers Inc.

Woodhill, J. (2002) Sustainability, social learning and the democratic imperative. Lessons from the Australian Landcare movement. In: Leeuwis, C. and R. Pyburn (Eds) (2002), pp. 317-331. 